\title{
The long-run determination of the real exchange rate. Evidence from an intertemporal modelling framework using the dollar-pound exchange rate.
}

\author{
Ioannis Litsios $^{1} \cdot$ Keith Pilbeam $^{2}$
}

Published online: 7 October 2017

(C) The Author(s) 2017. This article is an open access publication

\begin{abstract}
This paper develops a model of optimal choice over an array of different assets, including domestic and foreign bonds, domestic and foreign equities and domestic and foreign real money balances to examine the determination of the real exchange rate in the long-run. The model is tested empirically using data from the UK and the USA. The results show that all the coefficients of the model are right signed and significant and consequently financial assets may play a significant role in the determination of the real exchange rate.
\end{abstract}

Keywords Real exchange rate - Intertemporal model $\cdot$ Asset prices · Vector Error Correction Model

JEL Classification $\mathrm{F} 31 \cdot \mathrm{G} 11$

\section{Introduction}

Trying to estimate the equilibrium real exchange rate (ERER) remains a major challenge in modern international finance. A fundamental problem is that the equilibrium real exchange rate is not observable. In addition, according to Rogoff (1996) deviations of the actual real exchange rate from its long-run parity could be linked to the behaviour of macroeconomic fundamentals. In fact, many theoretical models have been constructed based on the premise that the ERER is a function of macroeconomic fundamentals.

Keith Pilbeam

K.S.Pilbeam@city.ac.uk

Ioannis Litsios

I.Litsios@bradford.ac.uk

1 Division of Economics, University of Bradford, Bradford, UK

2 Department of Economics, City, University of London, London, UK 
The standard models in the literature on the determination of the ERER emerge from a simple balance of payments equilibrium equation, the so-called statistical equilibrium; see for example McDonald (2000). The most simple model is the purchasing power parity (PPP) model which implies that the real exchange rate does not change in terms of tradable goods prices but allows for deviations based on price indices made up of both tradable and non-tradable goods. However, the empirical evidence suggests that deviations from PPP can be both substantial and persistent in nature. ${ }^{1}$ Given that PPP is not able to explain the behaviour of the ERER it has been argued that such a measurement can be derived from an economic model in which macroeconomic fundamentals are explicitly present. Different approaches like the behavioural equilibrium exchange rate (BEER) of Clark and MacDonald (1998) and Driver and Westaway (2004) and the fundamental equilibrium exchange rate (FEER) developed by Williamson (1994) have emerged.

This paper contributes to the literature by proposing an alternative approach to the determination of the real exchange rate in the long-run. As opposed to the current literature, which is heavily based on various extensions of the balance of payments equilibrium real exchange rate equation, our proposed theoretical framework offers a portfolio balance approach to the determination of the real exchange rate in the long run by constructing a two country model with optimizing agents where wealth is assumed to be allocated optimally in an asset choice set that explicitly includes investment in an array of financial assets namely, money, bonds and shares. The model specification introduced in this paper allows the construction of explicit equations for both domestic and foreign real money balances, domestic and foreign bond returns and domestic and foreign share prices to generate a relationship for the determination of the real exchange rate in the long-run. In this paper, we show that the theoretical model that we derive is empirically well supported by using the dollar-pound rate, indicating that asset prices and returns can play a substantive role in the determination of the real exchange rate in the long-run. Although Dellas and Tavals (2013) have recently shown a theoretical and empirical linkage between asset prices and exchange rate regimes, and Fratzscher et al. (2015) provide empirical evidence in favour of the scapegoat theory of exchange rates in understanding exchange rate fluctuations, our approach is to show an explicit link between asset prices, monetary factors and the real exchange rate. ${ }^{2}$

The rest of this paper is organised as follows: Section 2 presents an intertemporal optimization model, as a contribution to the understanding of the determination of the real exchange rate in the long-run. Section 3 discusses the dataset and empirical methodology for examining the predicted relationship. Section 4 discusses the results from the empirical estimations and Section 5 concludes.

\section{The Model}

An infinitely lived representative agent (individual) is assumed to respond optimally to the economic environment. Utility is assumed to be derived from consumption of goods and from holdings of domestic and foreign real money balances. The

\footnotetext{
${ }^{1}$ This is the well-known 'PPP puzzle' as labelled by Rogoff (1996).

${ }^{2}$ See Bacchetta and van Wincoop $(2004,2013)$ for an analysis behind the scapegoat effect.
} 
consumption basket is assumed to be a composite bundle of goods produced both domestically and in the foreign economy. The presence of real money balances is intended to represent the role of money used in transactions, without addressing explicitly a formal transaction mechanism. This can distinguish money from other assets like interest bearing bonds or stocks. ${ }^{3}$ The representative agent is assumed to maximize the present value of lifetime utility given by:

$$
E_{t} \sum_{t=0}^{\infty} \beta^{t}\left[\frac{\left(C_{t}^{\alpha}\right)^{1-\sigma}}{1-\sigma}+\frac{X}{1-\varepsilon}\left(\left[\frac{M_{t}}{P_{t}}\right]^{\eta_{1}}\left[\left.\frac{M_{t}^{*}}{P_{t}^{*}}\right|^{\eta_{2}}\right)^{1-\varepsilon}\right]\right.
$$

where $C_{t}$ is real consumption of a composite bundle of goods, $\frac{M_{t}}{P_{t}}$ and $\frac{M_{t}^{*}}{P_{t}^{*}}$ are domestic and foreign real money balances respectively, $0<\beta<1$ is the individual's subjective time discount factor, $\sigma, \varepsilon, X$ are assumed to be positive parameters, with $0.5<\sigma<1$ and $0.5<\varepsilon<1$, and $E_{t}(\cdot)$ the mathematical conditional expectation at time $t$. For analytical tractability and following Kia's (2006) suggestion, we assume that, $\alpha, \eta_{1}$, and $\eta_{2}$ are all normalized to unity.

The present value of lifetime utility is assumed to be maximized subject to a sequence of budget constraints given by:

$$
\begin{gathered}
y_{t}+\frac{M_{t-1}}{P_{t}}+\frac{M_{t-1}^{*}}{e_{t} P_{t}}+\frac{B_{t-1}^{D}\left(1+i_{t-1}^{D}\right)}{P_{t}}+\frac{B_{t-1}^{F}\left(1+i_{t-1}^{F}\right)}{e_{t} P_{t}}+\frac{S_{t-1}\left(P_{t}^{S}+d_{t-1}\right)}{P_{t}}+\frac{S_{t-1}^{*}\left(P_{t}^{S, *}+d_{t-1}^{*}\right)}{e_{t} P_{t}}=(2) \\
C_{t}+\frac{M_{t}}{P_{t}}+\frac{M_{t}^{*}}{e_{t} P_{t}}+\frac{B_{t}^{D}}{P_{t}}+\frac{B_{t}^{F}}{e_{t} P_{t}}+\frac{S_{t} P_{t}^{S}}{P_{t}}+\frac{S_{t}^{*} P_{t}^{S, *}}{e_{t} P_{t}}
\end{gathered}
$$

where $y_{t}$ is current real income, $\frac{M_{t-1}}{P_{t}}$ and $\frac{M_{t-1}^{*}}{e_{t} P_{t}}$ are real money balances expressed in current domestic unit terms (with $M_{t-1}$ and $M_{t-1}^{*}$ domestic and foreign nominal money balances respectively carried forward from last period), $e_{t}$ the nominal exchange rate defined as the amount of foreign currency per unit of domestic currency and $P_{t}$ the price index of the composite good consumed domestically. $B_{t-1}^{D}$ is the amount of domestic currency invested in domestic bonds at $t-1$ and $i_{t-1}^{D}$ is the nominal rate of return on the domestic bonds. Similarly, $B_{t-1}^{F}$ is the amount of foreign currency invested in foreign bonds at $t-1$ and $i_{t-1}^{F}$ is the nominal rate of return on the foreign bonds. Both domestic and foreign bonds are assumed to be one period discount bonds paying off one unit of the relevant domestic currency next period. $S_{t-1}$ and $S_{t-1}^{*}$ denote the number of domestic and foreign shares respectively purchased at $t-1, P_{t}^{S}$ and $P_{t}^{S,{ }^{*}}$ denote the domestic

\footnotetext{
${ }^{3}$ A direct way to model the role of money in facilitating transactions would be to develop a time-shopping model after introducing leisure in the utility function. Another approach, commonly found in the literature, allows money balances to finance certain types of purchases through a cash-in-advance (CIA) modelling. For tractability reasons the specification expressed by Equation (1) is adopted in this paper. See Walsh (2003) for the various approaches in modelling the role of money in the utility function.
} 
and the foreign share prices respectively and $d_{t-1}$ and $d_{t-1}^{*}$ the value of the domestic and foreign dividends earned. ${ }^{4}$

The agent is assumed to observe the total real wealth and then proceed with an optimal consumption and portfolio allocation plan. The right hand side of eq. (2) indicates that total real wealth is allocated at time $t$ among real consumption of the composite good $\left(C_{t}\right)$, real domestic and foreign money balances $\left(\frac{M_{t}}{P_{t}}, \frac{M_{t}^{*}}{e_{t} P_{t}}\right)$, real domestic and foreign bond holdings $\left(\frac{B_{t}^{D}}{P_{t}}, \frac{B_{t}^{F}}{e_{t} P_{t}}\right)$, and real domestic and foreign equity holdings $\left(\frac{S_{t} P_{t}^{S}}{P_{t}}, \frac{S_{t}^{*} P_{t}^{S, *}}{e_{t} P_{t}}\right) .^{5}$

The representative agent is assumed to maximize eq. (1) subject to eq. (2). In order to get an analytical solution for the intertemporal maximization problem, the Hamiltonian equation is constructed and the following necessary first order conditions are derived:

$$
\begin{aligned}
& \beta^{t} U_{c, t}-\lambda_{t}=0 \\
& \beta^{t} U_{\frac{M}{P}, t} \frac{1}{P_{t}}-\lambda_{t} \frac{1}{P_{t}}+E_{t}\left[\lambda_{t+1} \frac{1}{P_{t+1}}\right]=0 \\
& \beta^{t} U_{\frac{M^{*}}{P^{*}}, t} \frac{1}{P_{t}^{*}}-\lambda_{t} \frac{1}{e_{t} P_{t}}+E_{t}\left[\lambda_{t+1} \frac{1}{e_{t+1} P_{t+1}}\right]=0 \\
& -\lambda_{t} \frac{1}{P_{t}}+E_{t}\left[\lambda_{t+1} \frac{1}{P_{t+1}}\left(1+i_{t}^{D}\right)\right]=0 \\
& -\lambda_{t} \frac{1}{e_{t} P_{t}}+E_{t}\left[\lambda_{t+1} \frac{1}{e_{t+1} P_{t+1}}\left(1+i_{t}^{F}\right)\right]=0 \\
& -\lambda_{t} \frac{P_{t}^{S}}{P_{t}}+E_{t}\left[\lambda_{t+1} \frac{1}{P_{t+1}}\left(P_{t+1}^{S}+d_{t}\right)\right]=0
\end{aligned}
$$

\footnotetext{
${ }^{4}$ It is assumed that the individual collects his dividend first and then goes out in the financial market to trade. In other words, the stock market opens after the realization of dividends.

${ }^{5}$ All variables are expressed in real domestic terms. 


$$
-\lambda_{t} \frac{P_{t}^{S, *}}{e_{t} P_{t}}+E_{t}\left[\lambda_{t+1} \frac{1}{e_{t+1} P_{t+1}}\left(P_{t+1}^{S, *}+d_{t}^{*}\right)\right]=0
$$

where $\lambda_{t}$ the costate variable, $U_{c, t}$, the marginal utility from consumption and $U_{\frac{M}{P}, t}, U_{\frac{M^{*}}{P^{*}}, t}$ the marginal utilities from domestic and foreign real money balances respectively.

It is further assumed that the representative agent consumes according to the following constant elasticity of substitution (CES) composite:

$$
C_{t}=\left[\alpha^{\frac{1}{\Theta}}\left(C_{t}^{h}\right)^{\frac{\Theta-1}{\Theta}}+(1-\alpha)^{\frac{1}{\Theta}}\left(C_{t}^{f}\right)^{\frac{\Theta-1}{\Theta}}\right]^{\frac{\Theta}{\Theta-1}}
$$

Where $C_{t}^{h}, C_{t}^{f}$ represent consumption of domestically produced goods and foreign imported goods respectively. The degree of home bias in preferences is given by parameter $\alpha \in[0,1]$ and can be perceived as a natural index of the degree of openness of the economy. Parameter $\Theta>1$ measures the substitutability between domestic and foreign goods.

Defining $P_{t}^{h}$ and $P_{t}^{f}$ as the price indexes of domestically produced goods and goods produced in the foreign economy (all expressed in units of domestic currency), the utility based consumer price index (CPI) of the composite good consumed domestically is given by:

$$
P_{t}=\left[\alpha\left(P_{t}^{h}\right)^{1-\Theta}+(1-\alpha)\left(P_{t}^{f}\right)^{1-\Theta}\right]^{\frac{1}{1-\Theta}}
$$

Given that the nominal exchange rate $e_{t}$ is the amount of foreign currency per unit of domestic currency we can write the domestic price equivalent $\left(P_{t}^{f}\right)$ of the price index of the goods produced in the foreign economy $\left(P_{t}^{f^{*}}\right)$ as $P_{t}^{f}=\frac{P_{t}^{f^{*}}}{e_{t}}$ and the foreign currency equivalent of the price index of domestically produced goods $\left(P_{t}^{h}\right)$ as $P_{t}^{h^{*}}=P_{t}^{h} e_{t}$.

Following Galí and Monacelli (2004) a simplifying assumption is introduced namely that there is no distinction between foreign CPI $\left(P_{t}^{*}\right)$ and the price index of the goods produced in the foreign economy $\left(P_{t}^{f^{*}}\right)$ i.e. $P_{t}^{f^{*}}=P_{t}^{* 6}$. The intuition of this is that PPP does hold for foreign (tradable) goods. This is not the case however for the domestic aggregate CPI. Assuming that the price index of domestically (non-traded) produced goods increases (given $P_{t}^{*}, P_{t}^{f^{*}}$ ) domestic consumers move towards foreign goods and a nominal depreciation is induced. Given the nominal depreciation $P_{t}^{f}$ will increase but given its composition $P_{t}$ will increase more that the nominal depreciation i.e. PPP fails to hold.

\footnotetext{
$\overline{6}$ This assumption is also employed in deriving equations 14 and 15.
} 
Consequently, the terms of trade $T_{t}$ and the real exchange rate $q_{t}$ are defined respectively as:

$$
\begin{gathered}
T_{t}=\frac{P_{t}^{f}}{P_{t}^{h}}=\frac{\frac{P_{t}^{f^{*}}}{e_{t}}}{P_{t}^{h}}=\frac{P_{t}^{f^{*}}}{e_{t} P_{t}^{h}}=\frac{P_{t}^{f^{*}}}{P_{t}^{h^{*}}} \\
q_{t}=\frac{\frac{P_{t}^{*}}{e_{t}}}{P_{t}}=\frac{P_{t}^{*}}{e_{t} P_{t}}
\end{gathered}
$$

$q_{t}$ denotes the real exchange rate defined as $q_{t}=\frac{P_{t}^{*}}{e_{t} P_{t}}$ where $P_{t}$ and $P_{t}^{*}$ the price indexes of the composite bundles of goods consumed domestically and in the foreign economy. A rise in $q_{t}$ represents a real depreciation while a fall represents a real appreciation.

The static optimal allocation of total (composite) consumption leads to the following symmetric isoelastic demand functions for both domestic and foreign goods respectively ${ }^{7}$ :

$$
\begin{gathered}
C_{t}^{h}=\alpha\left(\frac{T_{t}}{q_{t}}\right)^{\Theta} C_{t} \\
C_{t}^{f}=(1-\alpha)\left(q_{t}\right)^{-\Theta} C_{t}
\end{gathered}
$$

Rewriting eq. (14) and eq. (15) in terms of real total consumption of the composite bundle consumed in the domestic economy leads to eqs. (16) and (17):

$$
\begin{gathered}
C_{t}=\frac{C_{t}^{h}}{\alpha\left(\frac{T_{t}}{q_{t}}\right)^{\theta}} \\
C_{t}=\frac{C_{t}^{f}}{(1-\alpha) q_{t}^{-\theta}}
\end{gathered}
$$

Dividing eq. (5) by eq. (7) and using eq. (3) yields eq. (18):

$$
U_{\frac{M^{*}}{P^{*}}, t}+U_{C, t}\left(1+i_{t}^{F}\right)^{-1} q_{t}=U_{C, t} q_{t}
$$

Equation (18) implies that the marginal benefit of holding additional foreign real money balances at $t$ must equal the marginal utility from consuming units

\footnotetext{
${ }^{7}$ Details of the formal derivation are available from the authors by request.
} 
of the domestic composite bundle of goods at time $t$. Note that the total marginal benefit of holding money at time $t$ is equal to the marginal utility from holding real money balances at $t$, as reflected by $U_{\frac{M^{*}}{P^{*}}, t}$, and the marginal utility from the consumption of the composite bundle of goods, given by $U_{C, t}$. Equation (18) can be rearranged in order to express the intratemporal marginal rate of substitution of composite domestic consumption for foreign real money balances as a function of the foreign bond return and the real exchange rate i.e. $\frac{U_{M^{*}, t}}{U_{C, t}^{*}}=\left\{1-\left[\left(1+i_{t}^{F}\right)^{-1}\right]\right\} q_{t}$.

Dividing eq. (5) by eq. (9) and using eq. (3) yields eq. (19) ${ }^{8}$ :

$$
U_{\frac{M^{*}}{P^{*}}, t}+U_{C, t}\left[\frac{P_{t+1}^{S, *}+d_{t}^{*}}{P_{t}^{S, *}}\right]^{-1} q_{t}=U_{C, t} q_{t}
$$

In a similar vein, eq. (19) can be rearranged to express the intratemporal marginal rate of substitution of composite domestic consumption for foreign real money balances as a function of the expected foreign stock return and the real exchange rate i.e.

$$
\frac{U_{M^{*}}, t}{P_{C, t}}=\left\{1-\left[\frac{P_{t+1}^{S, *}+d_{t}^{*}}{P_{t}^{S, *}}\right]^{-1}\right\} q_{t}
$$

Dividing eq. (4) by eq. (6) and using eq. (3) yields eq. (20):

$$
U_{\frac{M}{P}, t}+U_{c, t}\left(1+i_{t}^{D}\right)^{-1}=U_{c, t}
$$

Equation (20) implies that the marginal benefit of holding additional domestic real money balances at time $t$ must equal the marginal utility from consuming units of the domestic composite bundle of goods at time $t$. This can be rearranged to express the intratemporal marginal rate of substitution of composite domestic consumption for domestic real money balances as a function of the domestic bond return i.e. $\frac{U_{\frac{M}{P}, t}}{U_{C, t}}=\left\{1-\left[\left(1+i_{t}^{D}\right)^{-1}\right]\right\}$.

Finally, by dividing eq. (4) by eq. (8) and using eq. (3) yields eq. (21):

$$
U_{\frac{M}{P}, t}+U_{c, t}\left(\frac{P_{t+1}^{S}+d_{t}}{P_{t}^{S}}\right)^{-1}=U_{c, t}
$$

Equation (21) can be rearranged to express the intratemporal marginal rate of substitution of composite domestic consumption for domestic real money balances as a function of the expected domestic stock return i.e. $\frac{U_{\frac{M}{P}, t}}{U_{C, t}}=1-\left(\frac{P_{t+1}^{S}+d_{t}}{P_{t}^{S}}\right)^{-1}$

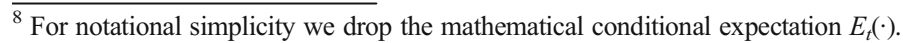


Using eq. (1) the marginal utility of consumption of the composite bundle of goods can be derived as follows:

$$
U_{c, t}=\beta^{t}\left(C_{t}\right)^{-\sigma}
$$

The marginal utilities for foreign and domestic real money balances are given respectively as:

$$
\begin{aligned}
& U_{\frac{M^{*}}{P^{*}}, t}=\beta^{t} X\left(\frac{M_{t}}{P_{t}}\right)^{1-\varepsilon}\left(\frac{M_{t}^{*}}{P_{t}^{*}}\right)^{-\varepsilon} \\
& U_{\frac{M}{P}, t}=\beta^{t} X\left(\frac{M_{t}^{*}}{P_{t}^{*}}\right)^{1-\varepsilon}\left(\frac{M_{t}}{P_{t}}\right)^{-\varepsilon}
\end{aligned}
$$

Equations (18), (22), (23) and (17) imply that:

$$
m_{t}^{*}=(1-\alpha)^{-\frac{\sigma}{\varepsilon}}\left(C_{t}^{f}\right)^{\frac{\sigma}{\varepsilon}}\left(q_{t}\right)^{\left[\frac{\sigma \theta-1}{\varepsilon}\right]} X^{\frac{1}{\varepsilon}}\left(m_{t}\right)^{\frac{(1-\epsilon)}{\epsilon}}\left[\frac{i_{t}^{F}}{1+i_{t}^{F}}\right]^{-\frac{1}{\varepsilon}}
$$

Equations (19), (22), (23) and (17) imply that:

$$
m_{t}^{*}=(1-\alpha)^{-\frac{\sigma}{\varepsilon}}\left(C_{t}^{f}\right)^{\frac{\sigma}{\varepsilon}}\left(q_{t}\right)^{\left[\frac{\sigma \theta-1}{\varepsilon}\right]} X^{\frac{1}{\varepsilon}}\left(m_{t}\right)^{\frac{(1-\epsilon)}{\epsilon}}\left[1-\left(\frac{P_{t+1}^{S, *}+d_{t}^{*}}{P_{t}^{S, *}}\right)^{-1}\right]^{-\frac{1}{\varepsilon}}
$$

Equations (20), (22), (24) and (16) imply that:

$$
m_{t}=\alpha^{-\frac{\sigma}{\varepsilon}}\left(C_{t}^{h}\right)^{\frac{\sigma}{\varepsilon}}\left(q_{t}\right)^{\frac{\sigma \theta}{\varepsilon}}\left(T_{t}\right)^{\frac{-\sigma \theta}{\varepsilon}} X^{\frac{1}{\varepsilon}}\left(m_{t}^{*}\right)^{\frac{1-\varepsilon}{\varepsilon}}\left[\frac{i_{t}^{D}}{1+i_{t}^{D}}\right]^{-\frac{1}{\varepsilon}}
$$

Finally, eqs. (21), (22), (24) and (16) imply that:

$$
m_{t}=\alpha^{-\frac{\sigma}{\varepsilon}}\left(C_{t}^{h}\right)^{\frac{\sigma}{\varepsilon}}\left(q_{t}\right)^{\frac{\sigma \theta}{\varepsilon}}\left(T_{t}\right)^{\frac{-\sigma \theta}{\varepsilon}} X^{\frac{1}{\varepsilon}}\left(m_{t}^{*}\right)^{\frac{1-\varepsilon}{\varepsilon}}\left[1-\left(\frac{P_{t+1}^{S}+d_{t}}{P_{t}^{S}}\right)^{-1}\right]^{-\frac{1}{\varepsilon}}
$$

Equations (25) to (28) reflect the demand equations for domestic and foreign real money balances that is, $m_{t}$ and $m_{t}^{*}$ respectively as implied by the economic model. This system of equations can be used in order to solve explicitly for the 
determinants of the real exchange rate. Substituting eq. (26) into eq. (27) and eq. (28) into eq. (25) yields eq. (29) ${ }^{9}$ :

$$
l q_{t}=\delta_{1}\left(l M_{t}\right)+\delta_{2}\left(l M_{t}^{*}\right)+\delta_{3}\left(l r_{t}\right)+\delta_{4}\left(l r_{t}^{*}\right)+\delta_{5}\left(l P_{t}^{S}\right)+\delta_{6}\left(l P_{t}^{F S, *}\right)
$$

Where: $\delta_{1}=-\left[\frac{2 \varepsilon-1}{1-\varepsilon}\right] ; \delta_{2}=\left[\frac{2 \varepsilon-1}{1-\varepsilon}\right] ; \delta_{3}=-\left[\frac{2 \varepsilon-1}{1-\varepsilon}\right] ; \delta_{4}=\left[\frac{2 \varepsilon-1}{1-\varepsilon}\right] ; \delta_{5}=-\left[\frac{\varepsilon}{1-\varepsilon}\right] ; \delta_{6}=\left[\frac{\varepsilon}{1-\varepsilon}\right]$;

Where $l q_{t}$ is the log of the real exchange rate; $l M_{t}$ is the log of the domestic nominal money supply; $l M_{t}^{*}$ is the $\log$ of the foreign nominal money supply; $l r_{t}$ is a proxy for the real return on domestic bonds; and $l r_{t}^{*}$ a proxy for the real return on foreign bonds,

The predictions of the model are that:

$\delta_{1}<0 ; \delta_{2}>0 ; \delta_{3}<0 ; \delta_{4}>0 ; \delta_{5}<0 ; \delta_{6}>0$

In addition, the following restrictions (as implied by the economic model) are assumed to hold. These restrictions are imposed on the long-run co-integrating vectors for the real exchange rate as derived in Section 3.

$$
\delta_{2}=-\delta_{1} ; \delta_{3}=\delta_{1} ; \delta_{4}=-\delta_{3} ; \delta_{6}=-\delta_{5}
$$

\section{Long-Run Empirical Methodology and Results}

In order to test empirically the validity of the economic predictions implied by eq. (29) in the long-run, a Vector Error Correction Model (VECM) of the following form is employed. $^{10}$

$$
\Delta \chi_{t}=\Gamma_{1}^{m} \Delta \chi_{t-1}+\Gamma_{2}^{m} \Delta \chi_{t-2}+\ldots+\Gamma_{k-1}^{m} \Delta \chi_{t-k+1}+\Pi \chi_{t-m}+\varepsilon_{t}
$$

where $\chi_{t}=\left(l q_{t}, l M_{t}, l M_{t}^{*}, l r_{t}, l r_{t}^{*}, l P_{t}^{F S^{*}} l P_{t}^{S}\right)$ a $(7 x 1)$ vector of variables, $m$ denotes the lag placement of the ECM term, ${ }^{11} \Delta$ denotes the difference, and $\Pi=a \beta^{\prime}$ with $a$ and $\beta$ (pxr) matrices with $r<p$, where $p$ the number of variables and $r$ the number of stationary co-integrated relationships.

To test for co-integration among a set of integrated variables the Full Information Maximum Likelihood (FIML) approach is employed as proposed by Johansen (1988, 1991). ${ }^{12}$ Having uniquely identified potential co-integrating vectors, stationarity among the variables can be tested, while imposing specific restrictions. The above

\footnotetext{
$\overline{{ }^{9} \text { A } l \text { before a variable denotes } l o g}$. See Appendix I for the full derivation of Equation (29) along with the various assumptions employed. Appendix II presents a table with all variables employed in the construction of the theoretical model.

${ }^{10}$ Some of the advantages of the VECM are that it reduces the multicollinearity effect in time series, that the estimated coefficients can be classified into short-run and long-run effects, and that the long-run relationships of the selected macroeconomic series are reflected in the level matrix $\Pi$ and so can be used for further cointegration analysis. See Juselius (2006).

${ }^{11}$ For an $I(1)$ analysis $m$ should be equal to 1 .

12 The main advantage of such an approach is that it is asymptotically efficient since the estimates of the parameters of the short-run and long-run relationships are carried out in a single estimation process. In addition, through the FIML procedure potential co-integrating relationships can be derived in an empirical model with more than two variables.
} 
methodology is applied to test for a potential long-run relationship among the macroeconomic variables depicted by eq. (29).

To test the model quarterly time series data for the United Kingdom and the USA are employed for the period 1988 Q1 to 2016 Q1for the variables depicted by eq. (29). ${ }^{13}$ The UK and the USA were selected in the analysis as both economies have financial systems based on financial markets rather than on the banking sector as in most European economies. The beginning of the sample period was employed due to data availability issues and because in the 1980's the UK fundamentally changed the definitions of its monetary aggregates ( $M 2$ definition of money supply in the UK now corresponds to $M 1$ in the USA) and both the UK and the USA deregulated their financial markets. ${ }^{14}$

In the empirical equation (29) $l q_{t}$ is the log of the UK bilateral real exchange rate defined as dollars per pound, $l M_{t}$ is the log of the UK nominal money supply $(M 2), l M_{t}^{*}$ is the $\log$ of the USA nominal money supply $(M 1), l P_{t}^{S}$ and $l P_{t}^{S, *}$ are the main stock market indices in the UK and the USA (FTSE 100 and SP500 respectively), $l e_{t}$ is the bilateral nominal exchange rate defined as dollars per pound, $l i_{t}^{h}$ is the log of $\frac{i_{t}^{D}}{1+i_{t}^{D}}$ where $i_{t}^{D}$ is the three month rate on the UK Treasury securities and $l i_{t}^{*}$ is the $\log$ of $\frac{i_{t}^{F}}{1+i_{t}^{F}}$ where $i_{t}^{F}$ is the three month USA Treasury bill rate, $l P_{t}$ the $\log$ of the CPI in the UK and $l P_{t}^{*}$ the $\log$ of the CPI in the USA.

In order to proceed with the VECM analysis the time series employed were tested first for stationarity. Table 1 presents the results from the Augmented Dickey-Fuller (ADF) test under the null of a unit root. Evidence suggests (given the various levels of significance) that the first differences of the variables appear to be stationary as opposed to their levels. Consequently, the variables can be considered to be integrated of order one, i.e. I (1), and co-integration among the variables is possible. ${ }^{15}$

Before testing for the co-integration rank, the appropriate lag length for the underlying empirical VECM model is identified based on the Lagrangian multiplier (LM) test for serial correlation of the residuals. ${ }^{16}$ The Johansen (1995) procedures were then applied to test for the co-integration rank. From the Trace test and the Max-Eigen test, two co-integrating vectors were employed. Table 2 presents the results of the cointegration rank test.

The rank of the $\Pi$-matrix was found to be $r=2$ implying that statistically a discrimination among two conditionally independent stationary relations is possible. The two unrestricted co-integration relations are uniquely determined but the question remains on whether they are meaningful for economic interpretation. Consequently, Johansen and Juselius (1994) identifying restrictions were imposed to distinguish among the vectors and ensure the uniqueness of the

\footnotetext{
${ }_{13}$ Data are collected from Datastream.

${ }^{14}$ Data from the United States are used as a proxy for foreign variables and data from the UK as proxies for domestic variables.

${ }^{15}$ For robustness purposes we have also performed the Kwiatkowski, Phillips, Schmidt, and Shin (KPSS) test with stationarity under the null. The KPSS also suggests that the variables are integrated of order one i.e. I(1).

${ }^{16}$ The AIC, SBA, HQ tests are employed for the lag order selection. Beginning with the lowest lag suggested by the tests (based on the SBC criterion) the serial correlation of the residuals is tested using the Lagrangian multiplier (LM) test.
} 
Table 1 Augmented Dickey-Fuller test for a unit root

\begin{tabular}{|c|c|c|c|c|}
\hline \multirow[t]{2}{*}{ Variable } & \multicolumn{2}{|c|}{ Test in levels } & \multicolumn{2}{|c|}{ Test in differences } \\
\hline & No Trend & Trend & No Trend & Trend \\
\hline$l q_{t}$ & $-3.29(0) \dagger$ & $-3.50(0) \dagger$ & $-9.27(1)^{*}$ & $-9.22(1)^{*}$ \\
\hline$l M_{t}$ & $-2.61(0)$ & $-0.53(0)$ & $-8.88(0)^{*}$ & $-9.24(0)^{*}$ \\
\hline$I M_{t}^{*}$ & $1.23(1)$ & $-0.61(1)$ & $-4.69(0)^{*}$ & $-4.97(0)^{*}$ \\
\hline$l r_{t}$ & $-0.74(1)$ & $-2.59(1)$ & $-5.96(0)^{*}$ & $-5.96(0)^{*}$ \\
\hline$l r_{t}^{*}$ & $-0.99(1)$ & $-2.27(1)$ & $-7.88(0)^{*}$ & $-7.83(0)^{*}$ \\
\hline$l P_{t}^{S}$ & $-1.98(0)$ & $-2.28(0)$ & $-10.67(0)^{*}$ & $-10,70(0)^{*}$ \\
\hline$l P_{t}^{F S, *}$ & $-1.69(0)$ & $-2.08(0)$ & $-11.00(0)^{*}$ & $-11.01(0)^{*}$ \\
\hline
\end{tabular}

Note: Entries in parenthesis indicate the lag length based on SIC maxlag $=12$

†indicates that the test is significant at $1 \%$ and $5 \%$

(*) indicates that the test is significant at all critical values.

coefficients. By taking a linear combination of the unrestricted $\beta$ vectors, it is always possible to impose $r-1$ just identifying restrictions and one normalization on each vector without changing the likelihood function. Although the normalization process can be done arbitrarily it is generally accepted practice to normalize on a variable that is representative of a particular economic relationship. Since the purpose of the paper is to identify a possible long-run determination of the real exchange rate, the co-intergrated vectors are normalized with respect to the real exchange rate. Additional restrictions (as implied by the

Table 2 Results of co-integration test

\begin{tabular}{cccc}
\hline No of co-integrated relationships & Trace Statistic & 5\% Critical Value & Probability \\
\hline None * & 168.5218 & 125.6154 & 0.0000 \\
At most 1 * & 111.6158 & 95.75366 & 0.0026 \\
At most 2 & 68.23399 & 69.81889 & 0.0664 \\
At most 3 & 35.09067 & 47.85613 & 0.4432 \\
At most 4 & 18.41248 & 29.79707 & 0.5357 \\
At most 5 & 6.411147 & 15.49471 & 0.6469 \\
At most 6 & 0.518945 & 3.841466 & 0.4713 \\
No of co-integrated relationships & Max -Eigen Statistic & $\mathbf{5 \%}$ Critical Value & Probability \\
None * & 56.90597 & 46.23142 & 0.0026 \\
At most 1 * & 43.38179 & 40.07757 & 0.0205 \\
At most 2 & 33.14333 & 33.87687 & 0.0610 \\
At most 3 & 16.67819 & 27.58434 & 0.6077 \\
At most 4 & 12.00133 & 21.13162 & 0.5475 \\
At most 5 & 5.892201 & 14.26460 & 0.6271 \\
At most 6 & 0.518945 & 3.841466 & 0.4713 \\
\hline
\end{tabular}

(*)denotes rejection of the hypothesis at the $5 \%(1 \%)$ level 
Table 3 Long-Run Co-integrating Relationship (constrained coefficients)

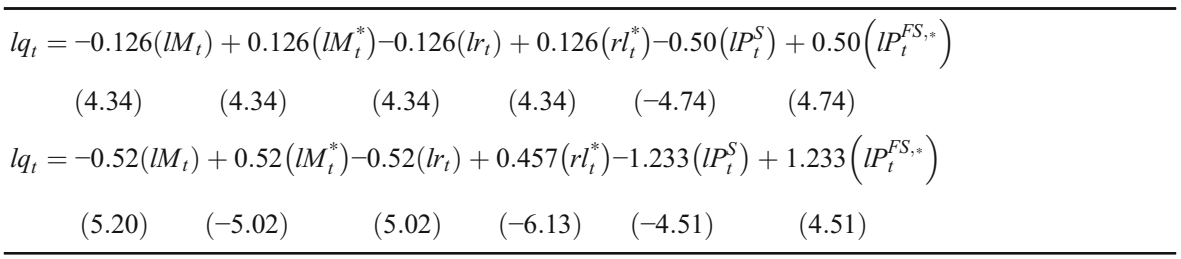

Note: $t$ statistics in parentheses

All constraint coefficient are statistically significant at 5\% level and correctly signed in accordance with the predictions of the model

economic model) are also imposed, namely that $\delta_{2}=-\delta_{1}, \delta_{3}=\delta_{1}, \delta_{4}=-\delta_{3}$ and $\delta_{6}=-\delta_{5}$.

In addition, all foreign variables, i.e. $l M_{t}^{*}, l r_{t}^{*}$ and $l P_{t}^{F S, *}$ are treated as weakly exogenous variables, thus long run forcing in the co-integrating space. This can be justified under the assumption that the UK is a small open economy, as such domestic policy decisions or more generally domestic economic activity do not have a significant impact on the evolution of foreign variables. Consequently, treating all variables as jointly endogenously determined would lead to inappropriate inference. The restrictions identify all co-integrating vectors, and according to Theorem 1 of Johansen and Juselius (1994) the rank condition is satisfied.

Table 3 reports the constrained coefficients from the long-run co-integrating relationships normalized with respect to $l q_{t}{ }^{17}$. In both vectors all variables are statistically significant and correctly signed in accordance with the predictions of the theoretical model. The results reveal that the stock market variables are highly associated with the real exchange rate in the long run as compared with bond returns and money balances. Fig. 1 presents the two co-integrating graphs showing evidence of stationarity. From both co-integrating vectors it can be estimated that the value for the parameter $\varepsilon$ lies between 0.5 and 1 as assumed in the theoretical set up. To test the stability of the VECM model the inverse roots of the characteristic AR polynomial are reported in Fig. 2. The analysis confirms that the VECM is stable since the inverted roots of the model lie inside the unit circle. Having established that the VECM is stable, the identified long-run co-integrating relationships, normalized on the real exchange rate, can be interpreted.

Table 4 reports the adjustment coefficients on the dynamics of the adjustment process towards equilibrium. With an adjustment coefficient of -0.25 in the first co-integrating equation there is evidence that the real exchange rate tends to stabilize itself by $25 \%$ per quarter. The adjustment coefficients of all other variables apart from the money balances turn out to be insignificant. Additional tests related to the statistical viability of the results indicate that there is no serial correlation of the residuals, no evidence of heteroscedasticity and that the residuals are normally distributed ${ }^{18}$.

\footnotetext{
${ }^{17}$ The two co-integrating vectors are linearly independent.

18 The Breusch-Godfrey serial correlation LM test reports a prob. $(\chi)^{2}=0.07$, the Breusch-Pagan-Godfrey a prob. $(\chi)^{2}=0.09$ and the Jarque-Bera Normality test a probability of 0.44 .
} 

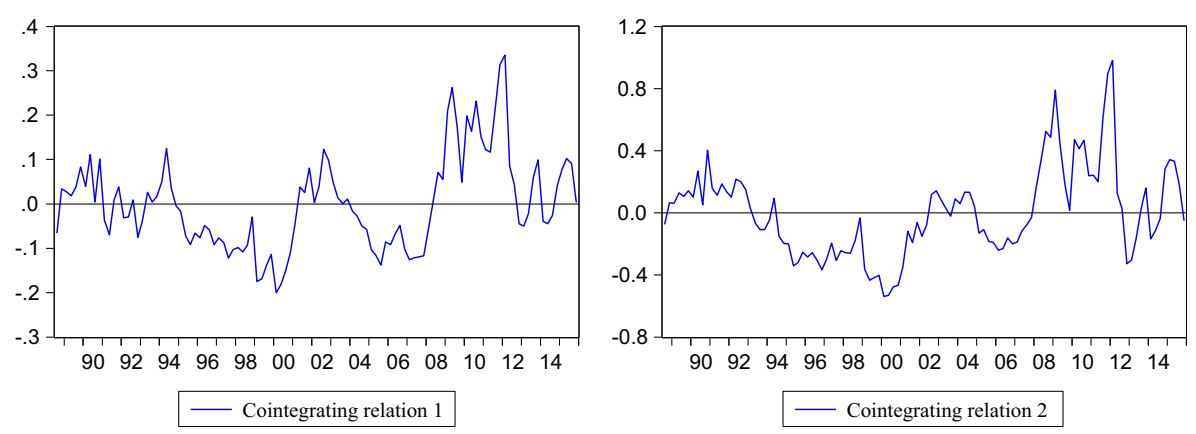

Fig. 1 The graphs of the co-integration relations

\section{Economic Interpretation of Results}

The model predicts that an expansionary monetary policy in the UK in a form of an increase in the nominal money supply will result in a real appreciation of the long run real exchange rate i.e. $\delta_{1}<0$. The estimated coefficient for the domestic (UK) nominal money supply $l M_{t}$, as depicted in Table 3 is negative supporting the prediction of the model. The prediction of the model regarding the increase in the domestic money supply is because in the long run the price level will accommodate the increase in the nominal money supply (given that money neutrality holds) but the nominal exchange rate depreciates to a lesser extent as PPP does not hold in the long run. In a similar manner, the model predicts real exchange rate depreciation after an increase in the foreign (USA) nominal money supply $l M_{t}^{*}\left(\delta_{2}>0\right)$. The coefficient for the foreign

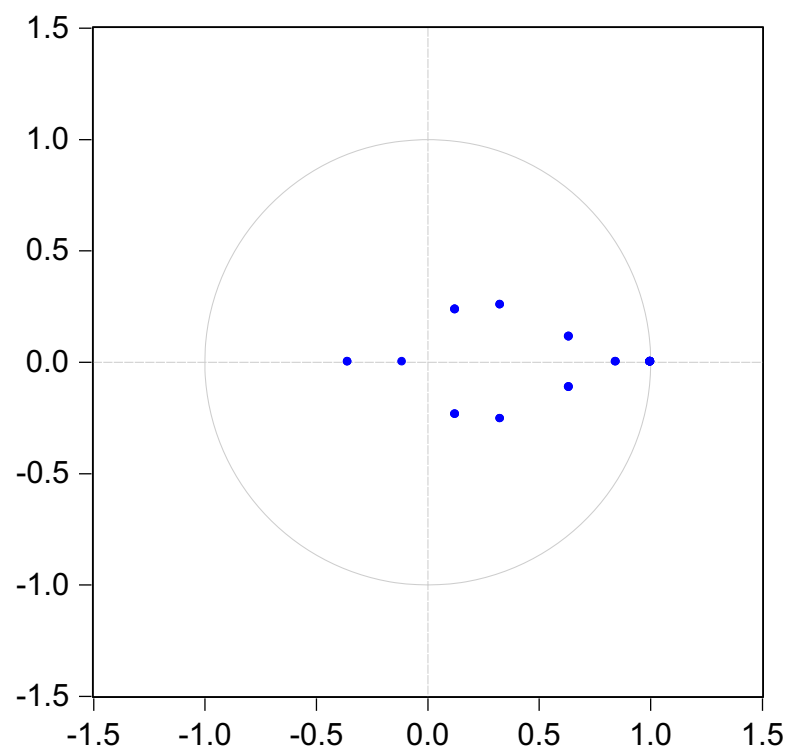

Fig. 2 Inverse roots of AR characteristic polynomial 
Table 4 Adjustment coefficients

\begin{tabular}{clllllllll}
\hline Variable & Coint. Eq 1 & Coint. Eq 2 & $\Delta l q_{t}$ & $\Delta l M_{t}$ & $\Delta l M_{t}^{*}$ & $\Delta l r_{t}$ & $\Delta r_{t}^{*}$ & $\Delta l P_{t}^{S}$ & $\Delta l P_{t}^{F S, *}$ \\
\hline Adjustment & -0.250 & 0.05 & 0.13 & 0.61 & 0.97 & -0.02 & -0.01 & 0.05 & -0.09 \\
Coefficient & $(-3.38)$ & $(1.91)$ & $(1.21)$ & $(2.61)$ & $(2.68)$ & $(-0.88)$ & $(-1.18)$ & $(0.72)$ & $(-1.51)$ \\
\hline
\end{tabular}

$\mathrm{t}$ statistics in parentheses

money supply has a positive sign, providing further evidence in favour of the theoretical model.

The model predicts that an increase in the real bond return $l r_{t}$ results in a long run real exchange rate appreciation i.e. $\delta_{3}<0$. The estimated coefficient in Table 3 for $l r_{t}$ is also negative supporting the prediction of the model. An explanation is that an increase in the real bond return may increase the demand of domestic currency, which induces both a nominal and real appreciation of the domestic currency in the long run. Likewise, the model predicts a real depreciation after an increase in the real foreign bond returns $l r_{t}^{*}$ i.e. $\delta_{4}>0$. This prediction is also borne out in our empirical test of the model.

Finally, the model predicts that an increase in the domestic (UK) share price index will lead into a real appreciation of the long run real exchange rate i.e. $\delta_{5}<$ 0 , which is confirmed in our results. The relationship between stock prices and exchanges rates that has been examined in the literature depends on the relative strengths of the income and substitution effects. A possible explanation for the appreciation of the real exchange rate (also predicted by the theoretical model) could be associated with a domination of the income effect and the subsequent increase in the demand for real money balances. The subsequent increase in the interest rate (in order to satisfy equilibrium in the money market) induces capital inflows and results in both a nominal and a real appreciation. Similarly, an increase in the foreign (USA) stock market index leads to a real depreciation of the exchange rate i.e. $\delta_{6}>0$, which is also confirmed by our results.

\section{Concluding Remarks}

This paper contributes towards the theoretical determination of the real exchange rate by constructing an intertemporal optimization model, which incorporates investment in an array of assets such as domestic and foreign bonds, domestic and foreign stocks, and domestic and foreign real money balances. Such an approach to the determination of the real exchange rate in the long-run has been neglected in the current literature, which is heavily based on the BEER and FEER models as well as on other extensions of the basic balance of payment equilibrium approach. 
The basic predictions of the model are borne out empirically suggesting that asset prices and returns play an important role in the determination of the long run real exchange rate and its evolution. The model suggests that an increase in the domestic money supply, an increase in the domestic real bond returns and an increase in the domestic economy's stock market will lead into a real exchange rate appreciation in the long run while increases in the corresponding foreign variables will lead to a real exchange rate depreciation. Given the importance of the role of the real exchange rate for policy makers and the functioning of open economies our contribution provides an alternative framework to much of the existing literature.

Our results suggest that future research would benefit from incorporating a range of asset prices when considering the equilibrium real exchange rate. There is also scope for future research to consider how mispricing of financial assets may also have feedback effects on the real exchange rate and hence on the real economy. It would also be interesting to compare the results of our model with the alternative methods of modelling the real exchange rate to see the extent of any quantitative and qualitative differences.

Acknowledgements We are extremely grateful to George Chortareas, Jose Olmo, Gabriel Montes-Rojas, Sushanta Mallick, William Pouliot, Roy Bailey, Keith Cuthbertson and Joscha Beckmann and the participants at the European Economics and Finance Society 15th Annual Conference in Amsterdam for many useful comments and suggestions. We are also particularly heavily indebted to two anonymous referees for their extensive comments that led to significant improvements in the paper. Any errors and omissions remain those of the authors.

\section{APPENDIX I}

\section{The derivation of the real exchange rate equation}

Substituting equation (26) into equation (27) and equation (28) into equation (25) in the text the following equation is derived:

$$
\frac{m_{t}}{m_{t}^{*}}=\frac{\alpha^{-\frac{\sigma}{\varepsilon}}\left(C_{t}^{h}\right)^{\frac{\sigma}{\varepsilon}}\left(q_{t}\right)^{\frac{\sigma \theta}{\varepsilon}}\left(T_{t}\right)^{\frac{-\sigma \theta}{\varepsilon}} X^{\frac{1}{\varepsilon}}\left\{(1-\alpha)^{-\frac{\sigma}{\varepsilon}}\left(C_{t}^{f}\right)^{\frac{\sigma}{\varepsilon}}\left(q_{t}\right)^{\left[\frac{\sigma \theta-1}{\varepsilon}\right]} X^{\frac{1}{\varepsilon}}\left(m_{t}\right)^{\frac{(1-\epsilon)}{\varepsilon}}\left[1-\left(\frac{P_{t+1}^{S, *}+d_{t}^{*}}{P_{t}^{S, *}}\right)^{-1}\right]^{-\frac{1}{\varepsilon}}\right\}^{\frac{1-\varepsilon}{\varepsilon}}\left[\frac{i_{t}^{D}}{1+i_{t}^{D}}\right]^{-\frac{1}{\varepsilon}}}{(1-\alpha)^{-\frac{\sigma}{\varepsilon}}\left(C_{t}^{f}\right)^{\frac{\sigma}{\varepsilon}}\left(q_{t}\right)^{\left[\frac{\sigma \theta-1}{\varepsilon}\right]} X^{\frac{1}{\varepsilon}}\left\{\alpha^{-\frac{\sigma}{\varepsilon}}\left(C_{t}^{h}\right)^{\frac{\sigma}{\varepsilon}}\left(q_{t}\right)^{\frac{\sigma \theta}{\varepsilon}}\left(T_{t}\right)^{\frac{-\sigma \theta}{\varepsilon}} X^{\frac{1}{\varepsilon}}\left(m_{t}^{*}\right)^{\frac{1-\varepsilon}{\varepsilon}}\left[1-\left(\frac{P_{t+1}^{S}+d_{t}}{P_{t}^{S}}\right)^{-1}\right]^{-\frac{1}{\varepsilon}}\right\}^{\frac{1-\epsilon}{\varepsilon}}\left[\frac{i_{t}^{F}}{1+i_{t}^{F}}\right]^{-\frac{1}{\varepsilon}}}
$$

which simplifies to:

$$
\frac{m_{t}}{m_{t}^{*}}=\left(\frac{\alpha}{1-\alpha}\right)^{-\frac{\sigma}{\varepsilon}}\left(\frac{C_{t}^{h}}{C_{t}^{f}}\right)^{\frac{\sigma}{\varepsilon}}\left(q_{t}\right)^{\left[\frac{\sigma \theta t}{\varepsilon}\right]}\left(q_{t}\right)^{-\left[\frac{\sigma \theta-1}{\varepsilon}\right]}\left(s_{t}\right)^{\frac{-\sigma \theta}{\varepsilon}}\left(\frac{1-\alpha}{\alpha}\right)^{\left[-\frac{\sigma(1-\varepsilon)}{\varepsilon}\right]}\left(\frac{C_{t}^{f}}{C_{t}^{h}}\right)^{\left[\frac{\sigma(1-\varepsilon)]}{\varepsilon}\right]}\left(q_{t}\right)^{-\left[\frac{1-\sigma \theta}{\varepsilon}\right]\left[\frac{1-\varepsilon]}{\varepsilon}\right]}\left(q_{t}\right)^{-\left[\frac{[\theta \theta}{\varepsilon}\right]\left[\frac{1-\varepsilon]}{\varepsilon}\right]}\left(s_{t}\right)^{\left[\frac{\sigma \theta}{\varepsilon}\right]\left[\frac{1-\varepsilon \varepsilon}{\varepsilon}\right]} \Omega
$$


where $\Omega=\frac{\left(\left(m_{t}\right)^{\frac{1-\epsilon}{\epsilon}}\right)^{\frac{1-\varepsilon}{\varepsilon}}\left\{\left[1-\left(\frac{P_{t+1}^{S *}+d_{t}^{*}}{P_{t}^{S, *}}\right)^{-1}\right]^{-\frac{1}{\varepsilon}}\right\}^{\frac{1-\varepsilon}{\varepsilon}}\left[\frac{i_{t}^{D}}{1+i_{t}^{D}}\right]^{-\frac{1}{\varepsilon}}}{\left(\left(m_{t}^{*}\right)^{\frac{1-\epsilon}{\epsilon}}\right)^{\frac{1-\varepsilon}{\varepsilon}}\left\{\left[1-\left(\frac{P_{t+1}^{S}+d_{t}}{P_{t}^{S}}\right)^{-1}\right]^{-\frac{1}{\varepsilon}}\right\}^{\frac{1-\epsilon}{\epsilon}}\left[\frac{i_{t}^{F}}{1+i_{t}^{F}}\right]^{-\frac{1}{\varepsilon}}}$

$$
\begin{gathered}
\frac{m_{t}}{m_{t}^{*}}=\left(\frac{C_{t}^{h}}{C_{t}^{f}}\right)^{-\frac{\sigma}{\varepsilon}}\left(T_{t}\right)^{\frac{\sigma \theta}{\varepsilon}}\left(\frac{C_{t}^{h}}{C_{t}^{f}}\right)^{\frac{\sigma}{\varepsilon}}\left(q_{t}\right)^{\frac{\sigma \theta}{\varepsilon}-\left[\frac{\sigma \theta-1}{\varepsilon}\right]}\left(T_{t}\right)^{\frac{-\sigma \theta}{\varepsilon}}\left(q_{t}\right)^{-\left[\frac{1-\sigma \theta}{\varepsilon}\right]\left[\frac{1-\varepsilon}{\varepsilon}\right]}\left(q_{t}\right)^{-\left[\frac{\sigma \theta}{\varepsilon}\right]\left[\frac{1-\varepsilon}{\varepsilon}\right]} \Omega \\
\frac{m_{t}}{m_{t}^{*}}=\left(q_{t}\right)^{\left[\frac{2 \varepsilon-1}{\varepsilon^{2}}\right]} . \Omega
\end{gathered}
$$

Dividing equation (6) with equation (8) yields that: $\frac{1}{P_{t}^{S}}=\frac{1+i_{t}^{D}}{P_{t+1}^{S}+d_{t}}$, which implies that:

$$
P_{t}^{S}-\left[P_{t+1}^{S}+d_{t}\right]=-\left[P_{t+1}^{S}+d_{t}\right] \frac{i_{t}^{D}}{1+i_{t}^{D}}
$$

In a similar manner dividing equation (7) with equation (9) implies that:

$$
P_{t}^{S,{ }^{*}}-\left[P_{t+1}^{S, *}+d_{t}^{*}\right]=-\left[P_{t+1}^{S, *}+d_{t}^{*}\right] \frac{i_{t}^{F}}{1+i_{t}^{F}}
$$

Using Equations (32) and (33) and dividing equation (8) with equation (9) implies that $\frac{P_{t}^{S}}{P_{t}^{S, *}}=\frac{e_{t+1}}{e_{t}} \cdot \frac{P_{t+1}^{S}+d_{t}}{P_{t+1}^{S, *}+d_{t}^{*}}$, Equation (31) becomes

$$
\frac{m_{t}}{m_{t}^{*}}=\left(q_{t}\right)^{\left[\frac{2 \varepsilon-1}{\varepsilon^{2}}\right]}\left(m_{t}\right)^{\left[\frac{(1-\epsilon)^{2}}{\epsilon^{2}}\right]}\left(m_{t}^{*}\right)^{\left[-\frac{(1-\epsilon)^{2}}{\epsilon^{2}}\right]}\left[P_{t+1}^{S * *}+d_{t}^{*}\right]^{-\left[\frac{1-\varepsilon}{\varepsilon^{2}}\right]}\left(i_{t}^{*}\right)^{-\left[\frac{1-\varepsilon}{\varepsilon^{2}}\right]} e_{t}^{-\left[\frac{1-\varepsilon}{\varepsilon^{2}}\right]} P_{t}^{S^{-\left[\frac{1-\varepsilon}{\varepsilon^{2}}\right]}} e_{t+1}^{\left[\frac{1-\varepsilon}{\varepsilon^{2}}\right]} P_{t}^{S, *\left[\frac{1-\varepsilon}{\varepsilon^{2}}\right]}
$$

$$
\left[P_{t+1}^{S}+d_{t}\right]^{\left[\frac{1-\varepsilon}{\varepsilon^{2}}\right]}\left(i_{t}^{h}\right)^{\left[\frac{1-\varepsilon}{\varepsilon^{2}}\right]}\left(i_{t}^{h}\right)^{-\left[\frac{1}{\varepsilon}\right]}\left(i_{t}^{*}\right)^{\left[\frac{1}{\varepsilon}\right]}
$$

Where $\left(i_{t}^{h}\right)=\left[\frac{i_{t}^{D}}{1+i_{t}^{D}}\right]$ and $\left(i_{t}^{*}\right)=\left[\frac{i_{t}^{F}}{1+i_{t}^{F}}\right]$

Taking logs of all variables we obtain equation (34): ${ }^{19}$

$$
l q_{t}=\delta_{1}\left(l M_{t}\right)+\delta_{2}\left(l M_{t}^{*}\right)+\delta_{3}\left(l r_{t}\right)+\delta_{4}\left(l r_{t}^{*}\right)+\delta_{5}\left(l P_{t}^{S}\right)+\delta_{6}\left(l P_{t}^{F S, *}\right)
$$

Where: $\delta_{1}=-\left[\frac{2 \varepsilon-1}{1-\varepsilon}\right] ; \delta_{2}=\left[\frac{2 \varepsilon-1}{1-\varepsilon}\right] ; \delta_{3}=-\left[\frac{2 \varepsilon-1}{1-\varepsilon}\right] ; \delta_{4}=\left[\frac{2 \varepsilon-1}{1-\varepsilon}\right] ; \delta_{5}=-\left[\frac{\varepsilon}{1-\varepsilon}\right] ; \delta_{6}=\left[\frac{\varepsilon}{1-\varepsilon}\right]$

Equation (34) corresponds to equation (29) in the text.

\footnotetext{
${ }^{19}$ Following the fact that $\frac{P_{t}^{S}}{P_{t}^{S, *}}=\frac{e_{t+1}}{e_{t}} \cdot \frac{P_{t+1}^{S}+d_{t}}{P_{t+1}^{S, *}+d_{t}^{*}}$ and assuming that capital and consumption are homogeneous goods. A $l$ before a variable denotes $\log$.
} 


\section{APPENDIX II}

\section{Variable Explanation}

$C_{t} \quad$ Real consumption of a composite bundle of goods

$m_{t}=\frac{M_{t}}{P_{t}} \quad$ Domestic real money balances, with $M_{t}$ domestic nominal money balances and $P_{t}$ the consumer price index of the composite good consumed domestically.

$m_{t}^{*}=\frac{M_{t}^{*}}{P_{t}^{*}}$ Foreign real money balances, with $M_{t}^{*}$ foreign nominal money balances and $P_{t}^{*}$ the consumer price index of the composite good consumed in the foreign economy.

$y_{t} \quad$ Real income

$e_{t} \quad$ Nominal exchange rate (amount of foreign currency per unit of domestic currency)

$B_{t}^{D} \quad$ Amount of domestic currency invested in domestic bonds

$B_{t}^{F} \quad$ Amount of foreign currency invested in foreign bonds

$i_{t}^{D} \quad$ Nominal rate of return on domestic bonds

$i_{t}^{F} \quad$ Nominal rate of return on foreign bonds

$S_{t} \quad$ Number of domestic shares purchased

$S_{t}^{*} \quad$ Number of foreign shares purchased

$P_{t}^{S} \quad$ Domestic share price

$P_{t}^{S, *} \quad$ Foreign share price

$d_{t} \quad$ Value of domestic dividend earned

$d_{t}^{*} \quad$ Value of foreign dividend earned

$U_{c, t} \quad$ Marginal utility from consumption

$U_{\frac{M}{P}, t} \quad$ Marginal utility from domestic real money balances

$U_{\frac{\underline{M}^{*}}{*}, t} \quad$ Marginal utility from foreign real money balances

$C_{t}^{h^{h^{*}}} \quad$ Consumption of domestically produced goods

$C_{t}^{f} \quad$ Domestic consumption of foreign imported goods

$P_{t}^{h} \quad$ The price index of domestically produced goods

$P_{t}^{f} \quad$ Price index of goods produced in the foreign economy (expressed in units of domestic currency)

$P^{f *} \quad$ Price index of goods produced in the foreign economy

$P^{h^{*}} \quad$ Foreign currency equivalent of the price index of domestically produced goods

$T_{t} \quad$ Terms of trade

$q_{t} \quad$ Real exchange rate - a rise represents a real depreciation a fall represents a real appreciation

$i_{t}^{h} \quad\left[\frac{i_{t}^{D}}{1+i_{t}^{D}}\right]$

$i_{t}^{*} \quad\left[\frac{i_{t}^{F}}{1+i_{t}^{F}}\right]$

$l P_{t}^{F S, *} \quad l P_{t}^{S, *}-l e_{t}(l$ denotes $\log )$

$l r_{t} \quad l i_{t}^{h}-l P_{t}(l$ denotes $\log )$

$l r_{t}^{*} \quad l i_{t}^{*}-l P_{t}^{*}(l$ denotes $\log )$

Open Access This article is distributed under the terms of the Creative Commons Attribution 4.0 International License (http://creativecommons.org/licenses/by/4.0/), which permits unrestricted use, distribution, and reproduction in any medium, provided you give appropriate credit to the original author(s) and the source, provide a link to the Creative Commons license, and indicate if changes were made. 


\section{Reference}

Bacchetta P, van Wincoop E (2004) A scapegoat model of exchange rate determination. Am Econ Rev 96: 552-576

Bacchetta P, van Wincoop E (2013) On the unstable relationship between exchange rates and macroeconomic fundamentals. J Int Econ 91:18-26

Clark, P. and MacDonald, R. (1998) Exchange rates and economic fundamentals: A methodological comparison of BEERs and FEER's, IMF Working Paper WP98/67

Dellas H, Tavals G (2013) Exchange rate regimes and asset prices. J Int Money Financ 38:85-94

Driver, R.L. and Westaway, P.F. (2004) Concepts of equilibrium exchange rates, Bank of England, Working Paper No. 248

Fratzscher M et al (2015) The scapegoat theory of exchange rates: The first tests. J Monet Econ 70:1-21

Galí J, Monacelli T (2004) Monetary policy and exchange rate volatility in a small open economy. Rev Econ Stud 72:704-734

Johansen S (1988) Statistical analysis in co-integrated vectors. J Econ Dyn Control 12:231-254

Johansen S (1991) Estimation and hypothesis testing of co-integration vectors in gaussian vector autoregressive models. Econometrica 52:389-402

Johansen S, Juselius K (1994) Identification of the long-run and short-run structure: an application to the ISLM model. J Econ 63:7-36

Johansen S (1995) Likelihood-based inference in cointegrated vector autoregressive models, Advanced texts in econometrics. Oxford University Press, Oxford

Juselius K (2006) The cointegrated VAR model: Methodology and applications. Oxford University Press, Oxford

Kia A (2006) Deficits, Debt financing, monetary policy and inflation in developing countries: internal or external factors? Evidence from Iran. J Asian Econ 17:879-903

MacDonald, R. (2000) Concepts to calculate equilibrium exchange rates: An overview, Deutsche Bundesbank No. 2000, 03

Rogoff K (1996) The purchasing power parity puzzle. J Econ Lit 34:647-668

Walsh CE (2003) Monetary theory and policy. Massachusetts Institute of Technology, Massachusetts

Williamson J (1994) Estimates of FEERs. In: Williamson J (ed) Estimating equilibrium exchange rates. Institute for International Economics, Washington D.C. 